\title{
The Industrial Structure Changes of Huaxi Village under the Macroeconomic Fluctuation
}

\author{
Yiying Zhang ${ }^{1, a}$ \\ ${ }^{1}$ School of History and Culture, Sichuan University, Chengdu City, Sichuan Province, China \\ a973825763@qq.com
}

Keywords: Huaxi Village; industrial structure change; rural enterprises; avoid economic crisis.

\begin{abstract}
In the late 1990s, the large-scale reforms of the rural enterprises occurred in South of Jiangsu. Being a typical rural enterprise in South of Jiangsu, Huaxi Village has experienced the household land the beginning of the reforms and the rural enterprises' political changes in late 1990s. And it can always avoid the disadvantages and being stable in the changes and achieve the steady growth, which caused the schloars' attention. However, the more important is how Huaxi Village keeps stable under the impacts of the economic crises which is different from the other rural enterprises' depression. The purpose of this paper is to analyze the reason why Huaxi Village has been able to grow steadily and to explore the further reasons why Huaxi Village has made this choice.
\end{abstract}

\section{Introduction}

Among the current researches, Huaxi Village's success is attributed to its socialist system, which has been one of the factors. For example, in the book of No. One Village in China: Post-collectivism of Huaxi Village's Economic Transformation, Yi Zhou (2006) proposed that Huaxi Village's industrial development system has influenced by its early collective ownership. And during this period, this village implemented the socialist collective economic development mode of "party-government-enterprise" [1]. In many media reports on Huaxi Village, its success relies in the political asylum, the geographical advantages, and the capable talents' hard work and governance. This paper attempts to get rid of the political interpretations and objectively analyzes its success from the perspective of the economic and institutional interpretations to increase the theoretical interpretation.

\section{Overview on the Development Background and Present Situation of Huaxi Village}

From a historical perspective, the industrialization process of the Yangtze River Delta Economic Zone has both global characteristics of China's industrialization and unique local advantages. According to Bo-zhong Li's study on the economy of South of Yangtze River, the value of industrial output in this area was relatively high in the periods of Jiaqing and Daoguang during Qing Dynasty. The industrial system here was more complete than other regions. [2] In addition, Huaxi Village is adjacent to Wuxi, Nanjing and Shanghai, and has its own location advantage. At the end of 1970s, the primitive accumulation of China's industry had basically taken shape; the area had relatively strong industry strength and pretty complete industrial layout. Meanwhile, villages in the south of Jiangsu province achieved original accumulation through internal self-deprivation; township enterprises also completed the original accumulation on the basis of cheap supply of production factors [3].

Being No. One Village in the World, Huaxi Village is a typical village in the south of Jiangsu province. The village experienced all of the above background. However, at present, Huaxi Village owns 8 major companies. In 2012, sales revenue of Huaxi was more than 50 billion yuan. Five industries here, including agriculture, manufacture, commercial, construction and tourism, can produce tens of thousands of products belongs to thousands of species. These products are now moving toward the international market. Meanwhile, from January to September 2012, available funds in Huaxi Village increased by $7.2 \%$ over the same period last year; by the end of 2012, the increase rate is expected to reach 10\%; paid taxes in the first 9 months was over 522 million yuan. A 
"Huaxi Village economic circle" which covers the whole country is taking shape [4]. The following figure shows the changes of output value in Huaxi Village since the village set up.

Figure 1 Output Values of Huaxi Village (unit: ten thousand yuan)

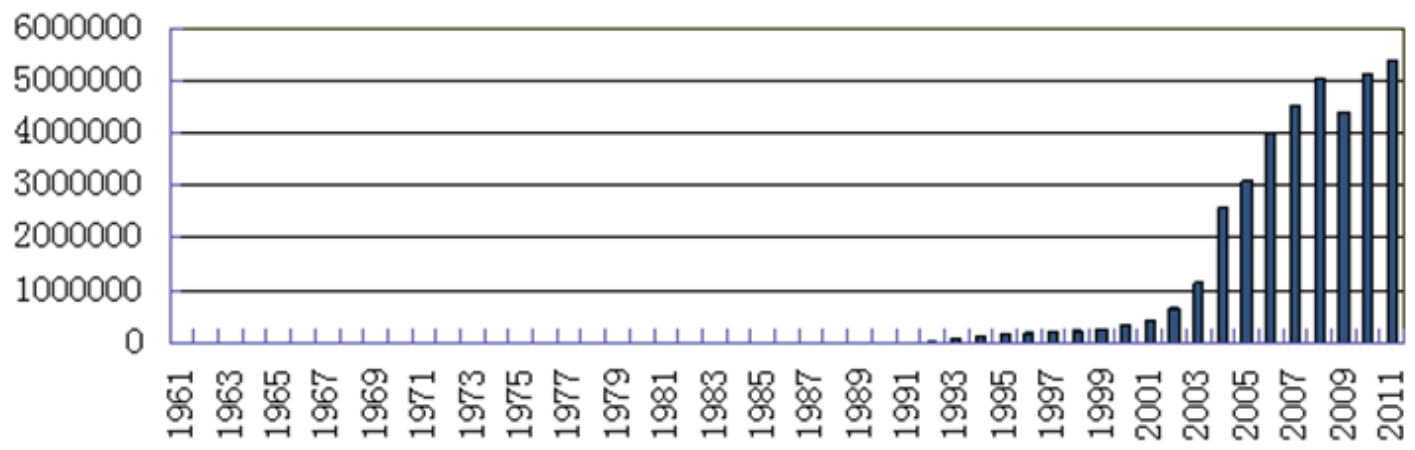

Data Source: Yearbook of Huashi Town

Huaxi Village completed the internal primitive accumulation in 1960s, and then adjusted its industrial structure. In 1990s, the village successfully got through the process of township enterprises restructuring and macroeconomic fluctuations. These outcomes are outstanding, but what did they do to achieve these objectives?

\section{Macroeconomic Fluctuations and Policy Changes}

Macroeconomic fluctuations and the reform of township enterprises. Economic crisis from 1978 to 1981 and the reform of agriculture, farmers and rural areas . China's GDP growth rate fell from $11.7 \%$ in 1981 to $5.2 \%$ in 1978 . In the market economy system, we always use this standard to evaluate economic crisis. At the same time,the growth rate of fixed-asset investment also declined continuously according to relevant statistics. [5]

Under these pressures, the central government adopted two kinds of policies towards rural areas. One was the full implementation of the basic economy system reform in rural areas, namely the implementation of household contract responsibility system; the other was the "capitalization of rural resources" based on rural industrialization and urbanization. Then, township enterprises became the best way to realize capitalization. These enterprises obtained the development opportunity.

The reform of township enterprises under the macroeconomic fluctuation in 1990s

Large-scale restructuring of township enterprises in southern region of Jiangsu began in 1990s. Before this, the region was known for collective economy, and ranked among rich regions. Survey of the nine villages from three counties in this region showed that, among the funds for township infrastructure construction, direct and indirect investment from township enterprises accounted for 81.2\%; financial output from the governments accounted for only $10.2 \%$. Consequently, local governments at all levels want to exit and get rid of the burden quickly. [6]

The development environment for township enterprises changed greatly. First change was the land factor. In 1980s, local governments promoted the development of enterprises through land occupation. At that period, most income from land occupation was used as initial capital to build township enterprises. This method caused two effects. One was the rapid decrease of cultivated land in China; two was the back-nurture of low cost social benefits to communities. With the increasing value of urban lands, various systems drew close to the beneficial mechanism of distributing land profit by the government. Second change was the manifestation of over-supply contradiction in domestic market. Chinese economy experienced great changes at that time. Domestic market turned from seller's market into buyer's market. Meanwhile, the lag phase of structural change of social demand appeared in China. The phenomena of overcapacity and soft market emerged.

These changes led township enterprises to a plight. Firstly, debt began to increase; secondly, the return rate of funds decreased; thirdly, the financial system reform led to a decline of credit availability of township enterprises. As a result, under the economic recession, township enterprises gradually came to debt crisis. After 1996, large-scale debt crisis formed with the macroeconomic downturn. 
Economic crisis in Southeast Asia in 1997. China's GDP growth rate dropped from $10.9 \%$ in 1998 to $7.8 \%$ in 1999, then to the lowest of $7.6 \%$ in 1995. In 1997, economic crisis in Southeast Asia outbroke. The economic system of Southeast Asia was based on export-oriented processing trade. Moreover, the macro-control of Chinese government in 1994 extended to the "soft landing" in 1997. Under the influence of these two factors, input economic crisis broke out in China in 1997, and then evolved into economic depression which was represented by deflation from 1998 to 1999. In 1998 and 1999, growth rate of fixed-asset investment in China declined to the lowest level in recent years. At the same time, the export growth was severely affected. The annual gross export value grew only $0.5 \%$. The pulling power of exports to economic growth decreased from $4.2 \%$ in 1997 to $1.3 \%$. It seemed necessary for township enterprises to reform under that situation.

Global economic crisis in 2008. In 2008, the Subprime Mortgage Crisis broke out in the United States, and then spread to the whole world. Global economic crisis arose. In China, signals of economic crisis appeared immediately. Firstly, the pulling power of export to GDP growth dropped from $2.6 \%$ of 2007 to $0.8 \%$ of 2008 . Secondly, serious inflation outbroke in China in 2008. The highest monthly CPI growth reached 8.7\%. These different economic indicators showed that in 2008, China's economy faced huge challenges.

\section{The Development Mechanism of Huaxi Village under the Economic Crises}

Primitive accumulation period (1960-1978). At the beginning of 1960s, the pillar industry of Huaxi Village was agriculture. Manufacture industry began to grow at the end of 60s. At that time there were only small metal factories and other small scale industries. The industry layout was point pattern distribution. At the end of 1960s, the political environment was not favorable to non-agricultural industrialization. In 1970s, the political environment became more favorable. The Second Plenary Session of the 9th Central Committee was held in Beijing in September, 1970. The government decided to speed up the modernization of rural areas and advocated the development of small local industrialization. Then the government put forward to the call of accelerating rural area modernization. However, Huaxi Village was a typical agricultural village at that time. Due to the impact of political environment, developing industry in Huaxi was still risky. The hardware factory of Huaxi Village was built in swamp. In 1978, Huaxi finally had the foundation to develop industry. The industrial output value reached 690 thousand and 500 yuan, accounting for more than $63 \%$ of the total output value.

In that stage, Huaxi completed the primitive accumulation of capital through internal primitive accumulation and the distribution method of self deprivation. Authorized village leaders were selected, and a reliable organization of Huaxi Village was established. At the same time, land was risk-free asset. Collective benefits were got through land revenue.

Multi-industry development stage. Bottom-fishing to avoid crisis (1978-2002). The year of 1978 was very important in the history of Huaxi Village. After 1978, Huaxi Village began to carry out diversified development. At the same time, in the increasingly saturated market, hardware products became unsalable. Ren-bao Wu believed that, if they could not find new breakthrough points before the hardware factory shut down, industry in Huaxi Village would be in danger. They chose the plastic textile industry according to market research information. In addition, Huaxi had geographical advantages and traditional technology advantages, since the village had a history of weaving and spinning and was located near the sources of textile raw materials. Afterwards, Huaxi Village entered the multi-industry development stage.

More accumulation and less distribution to build textile factories and obtain profits. The financial gap of establishing a plastic textile factory was 60 thousand yuan. Ren-bao Wu decided to raise money from local farmers. He persuaded villagers to get less annual bonus, and encouraged them to take out money. In 1979, the production value of Huaxi Village plastic textile factory was 1.19 million yuan, which the profit of 380 thousand yuan. In 1980, the earned money was used to expand reproduction. At first, the plastic textile factory had one spinning machine and twelve looms. After expansion the factory had six spinning machines and 96 looms. In 1981, the net profit of this factory was 1.6 million; in 1982 the net profit was 1.8 million. 
Keeping up with the changes of market situation; establishing new factories and creating new products. In 1982, after a lot of market research, Huaxi Village decided to invest medical instrument factory and produce sprayers. According to statistics, in 1983 and 1984, the factory produced about 1 million sprayers, and made net profit of about 4 million yuan. In 1980s, Huaxi Village cooperated with Hongkong Nengfeng International Corporation to build Jiangyin Bofeng Iron and Steel Co., Ltd. In 1987, the village cooperated with a steel company in Shanghai to build Huaxi Cold-rolling Strip Steel Factory. They invested 0.83 million and 3.5 million yuan respectively. In 1988, the annual output value of the cold rolled strip factory was 30 million. Until today, the factory remains the leading enterprise of Huaxi Village. Huaxi Village entered the steel industry in 1989, during the period of economic downturn. But the village made profit successfully.

In 1994, Huaxi Village actually completed the primitive accumulation of capital. The agriculture-based stage was over. The village used agricultural surplus as the foundation of industrial development though public-owned factories. In this way, different favorable opportunities can be grasped by Huaxi Village. Then the village can enter the market quickly at any stage.

The advantage of Huaxi Village at this stage is that, they adopted a pluralistic development of thinking, which reflected in their strategy of "various industries develop and extend; big enterprises are equally important with small ones; paying attention to the three main industries". They used the method of bottom-fishing to avoid economic crisis. Through the analysis of macro-economy, we can find that in 80s and 90s, China's capital market was in short supply. At that time, people with cash in their hands were "kings" of the market. Huaxi Village could provide funds quickly when developing steel and spray industries, and buying large numbers of raw materials. That was the key to win in economic recession periods.

Upgrading various industries to avoiding fluctuation (2002 to today). In twenty-first Century, Huaxi Village has entered a new stage of industrial structure adjustment and started to create new strategic layout. The industrial layout of Huaxi was formed. In addition to traditional industries of steel, cold-roll and textile, chemical fiber and other new industry factories were introduced. The third industry also developed rapidly. Reasonable industry layout of tourism, finance, aviation, logistics and sea transportation was formed. The industrial transformation of Huaxi Village was successful. It quickly went out of the impact of macroeconomic fluctuations, and avoided the crisis of low margin crisis of second industry through the development of the third industry and emerging industry. [7]

\section{Conclusions}

What are the further reasons for Huaxi Village to get through economic fluctuations?

As a common ownership village, Huaxi Village can use various means to accumulate the foundation of industrialization at the beginning of industrialization. So it started early in southern region of Jiangsu, and completed the primitive accumulation of capital. After 1978, when the market economy emerged, Huaxi Village formed the foundation of collective industrialization. Villagers agreed to use funds, labor, land and other factors, which reduced the cost of township enterprises development under the macro-economic environment at that time. The industrialization was protected. In the new century, through accelerating industrial restructuring and upgrading, Huaxi Village can avoid economic crisis and obtain stable flow of funds. It is a successful case of economic development among villages in southern regions of Jiangsu.

Furthermore, Huaxi Village has special capital accumulation, distribution and application mechanisms, and can response to market changes rapidly. The industrial structure of Huaxi Village gradually improves, in which different industries can promote each other. The extension of Coase's theory should mean that, internal villages transactions can save cost. Transaction costs between individuals, outside parties and villages can reduce. Once a village has several industries and a unified financial system, the three industries can support each, then the village will have quick response ability to the market. The village can timely eliminate old industries, enter new industries with high profit margins at any time, and get economic profits brought by policy and timely opportunities. It also can enter some industries at the bottom to avoid risks brought by economic fluctuations. Then the village can have unique advantages and realize the rapid economic 
development. Especially in the environment of capital shortage in 1980s and 1990s, people with cash could quickly win in the market.

Therefore, Huaxi Village's success cannot be understood only from the political or ideological aspect. It requires the multiple theories to explain the success of Huaxi Village.

\section{References}

[1] Yi Zhou. No. One Village in China: Post-collectivism of Huaxi Village's Economic Transformation. Oxford: Oxford University Press, 2006.

[2] Bo-zhong Li. Early Industrialization of the South of Yangtze River, 1550-1850. Social Sciences Academic Press, 2000.

Bo-zhong Li. Early Modern China Economy: A Study on the GDP of Huating and Lou County in the 1820s. Zhonghua Book Company, 2010.

[3] Tie-junWen, et al. Explorations into the South of Jiangsu Province. Suzhou University Press, 2011. 